\title{
Genotype-by-environment interaction in coast redwood outside natural distribution - search for environmental cues
}

\author{
Jaroslav Klápště ${ }^{*}$ (D), Dean Meason ${ }^{1}$, Heidi S. Dungey ${ }^{1}$, Emily J. Telfer $^{1}$, Paul Silcock ${ }^{2}$ and Simon Rapley ${ }^{3}$
}

\begin{abstract}
Background: Effective matching of genotypes and environments is required for the species to reach optimal productivity and act effectively for carbon sequestration. A common garden experiment across five different environments was undertaken to assess genotype $x$ environment interaction (GXE) of coast redwood in order to understand the performance of genotypes across environments.

Results: The quantitative genetic analysis discovered no GxE between investigated environments for diameter at breast height (DBH). However, no genetic component was detected at one environment possibly due to stressful conditions. The implementation of universal response function allowed for the identification of important environmental factors affecting species productivity. Additionally, this approach enabled us to predict the performance of species across the New Zealand environmental conditions.

Conclusions: In combination with quantitative genetic analysis which identified genetically superior material, the URF model can directly identify the optimal geographical regions to maximize productivity. However, the finding of ideally uncorrelated climatic variables for species with narrow ecological amplitude is rather challenging, which complicates construction of informative URF model. This, along with a small number of tested environments, tended to overfit a prediction model which resulted in extreme predictions in untested environments.
\end{abstract}

Keywords: Climate change, Clonal forestry, Universal response function, Genotype x environment interaction, Sequoia sempervirens

\section{Background}

Global climate change is expected to alter the net primary productivity of all terrestrial ecosystems over the next few decades. Understanding the effects on plant productivity, not only of the sequestration of carbon from elevated $\mathrm{CO}_{2}$ levels but also of interactions between carbon, nitrogen and water availability, is essential for the future sustainable management of natural resources [1]. Forest ecosystems have an important role in the global carbon cycle by storing carbon in the soil, live biomass, litter and deadwood. The amount of carbon stored is estimated to be around $45 \%$ of all terrestrial carbon [2]. The annual carbon uptake of forest ecosystems is approximately $2.3 \mathrm{Pg}$ of

*Correspondence: Jaroslav.Klapste@scionresearch.com

${ }^{1}$ Scion (New Zealand Forest Research Institute Ltd.), 49 Sala Street, 3010 Rotorua, New Zealand

Full list of author information is available at the end of the article
C per year, which represents approximately $33 \%$ of anthropogenic carbon emissions from fossil fuels and changes in land use $[2,3]$.

Changes in climate observed globally over a number of years are expected to continue and are likely to affect the types of trees that can be grown in particular environments [4]. Effective management of genetic resources for sustainable productivity and carbon sequestration of forests requires a good understanding of the full range of species genetic variability over a wide range of environments. Common garden experiments can be used to compare genetically distinct strains, families or populations under identical environmental conditions [5] and to dissect genetic divergence and phenotypic plasticity [6]. A number of common garden studies on various species have found significant proportions of phenotypic

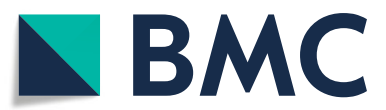

(C) The Author(s). 2020 Open Access This article is distributed under the terms of the Creative Commons Attribution 4.0 International License (http://creativecommons.org/licenses/by/4.0/), which permits unrestricted use, distribution, and reproduction in any medium, provided you give appropriate credit to the original author(s) and the source, provide a link to the Creative Commons license, and indicate if changes were made. The Creative Commons Public Domain Dedication waiver (http://creativecommons.org/publicdomain/zero/1.0/) applies to the data made available in this article, unless otherwise stated. 
variability in production traits (such as height or diameter) are caused by differences in climatic adaptation between populations along environmental gradients such as latitude [7-10] or altitude [11]. In the northern hemisphere, trees from southern/low elevation locations are consistently taller than trees from northern/high elevation areas, and these differences are associated with the number of frost-free days in the location of origin [7]. Therefore, planting populations from southern/low elevations in colder/higher environments may be required to compensate for global warming $[12,13]$ in order for species to remain effective production-wise and for carbon sequestration [14, 15]. Wang et al. [16] proposed universal response function as a combination of response and transfer function to capture these trends and make a well-informed decision about the optimal combination of genetic resources and growth conditions to maximise forest productivity under future predicted climate.

Coast redwood (Sequoia sempervirens (Lamb. Ex D. Don) Endl.) is a forest tree species that can sequester large amounts of carbon depending on the silvicultural regime used and the proportion of heartwood present [17], and its natural forests show a positive net carbon balance even under elevated stress conditions caused by drought [18]. Understanding the genotype $\mathrm{x}$ environment interaction $(\mathrm{GxE})$ of this species may lead to higher productivity and efficient carbon sequestration when optimal population for a suitable environment is identified.

Coast redwood naturally occurs along a narrow coastal strip ( $\sim 50 \mathrm{~km}$ width) of western North America ranging from Southern Oregon (OR) in the north to Southern California (CA) in the south [19]. Many sites in its natural range receive little summer precipitation, however, as most of its range occurs in Californian coastal fog belt, fog water is an important source of moisture for this forest ecosystem [20]. One study found that $45 \mathrm{~m}$ high adult trees require approximately 600 litres of water per day [20]. Ambrose et al. [21] found that coast redwood invests more resources in producing above-ground biomass than in a robust root system development, and concluded the species is susceptible to drought stress. The related species giant redwood (Sequoiadendron giganteum (Lindl.) J.Buchholz) has instead invested into more robust root system on account of reduces above-ground biomass production as a strategy to cope with drought. Coast redwood has few pest and diseases. Parts of redwood trees such as leaves, branchlets, roots and wood are rarely damaged by non-human animals presumably due to the volatile essential oils and tannins content. While there is a number of insects infesting coast redwood trees, none of them is capable of causing the death of mature trees [22]. Coast redwood leaves, branchlets, roots and wood are also notably decay-resistant, likely due to volatile essential oils (monoterpenoids and sesquiterpenoids) and tannins [19].

The objective of this study was to examine the genotype $x$ environment interaction $(\mathrm{GxE})$ of coast redwood by comparing tree growth among a number of different environments across New Zealand. We examined GxE interaction within a genetic framework using a range-wide collection of clones planted across 11 environments [23]. We used broad-sense heritability to assess the proportion of phenotypic variance explained by genotype, and the genetic correlation among sites to examine plasticity for two traits: productivity measured indirectly as stem diameter at breast height (DBH, $1.4 \mathrm{~m}$ ), and the occurrence of epicormic sprouts (EPI). We also investigated population response regarding environmental parameters at both origins and planted sites through the implementation of Universal response function. The implications of the gained knowledge on where to plant productive coast redwood for carbon are discussed.

\section{Results}

\section{Detection of population clusters and their correlations} with environmental variables

A cluster analysis based on geographical covariates and climatic variables generated only two significant clusters of genotypes, which were separated by location from the northern and southern parts of the US geographical distribution (data not shown). The second-best scenario defined by critical score detected 23 clusters (Fig. 1), which represented geographically unique and climatically homogeneous regions (Fig. 2 - right plot). The latter scenario was used in the subsequent analysis to obtain a more detailed insight into factors contributing to natural selection and genetic divergence.

\section{Genetic parameter estimates}

An analysis of each of the five sites (Additional file 1: Table S1) found virtually no genetic component at the Taupō site, and this site was therefore removed from all downstream analysis. We hypothesize that the lack of a genetic expression was likely from the significant site limitations on productivity at the Taupō site. These limitations will be discussed further in the discussion.

The multi-site variance component analysis of the four remaining sites generated statistically significant genetic components and heritabilities in both traits analysed. The genetic variance was partitioned into populations and genotype-within-population components, both of which were found to be statistically significant for the two traits (Table 1). The genotypic variance was prevalent in EPI but not in DBH, where differences between populations generally showed a larger proportion of genetic variance compared with the genotype-within-population variance. The population-level broad-sense heritability for DBH ranged 


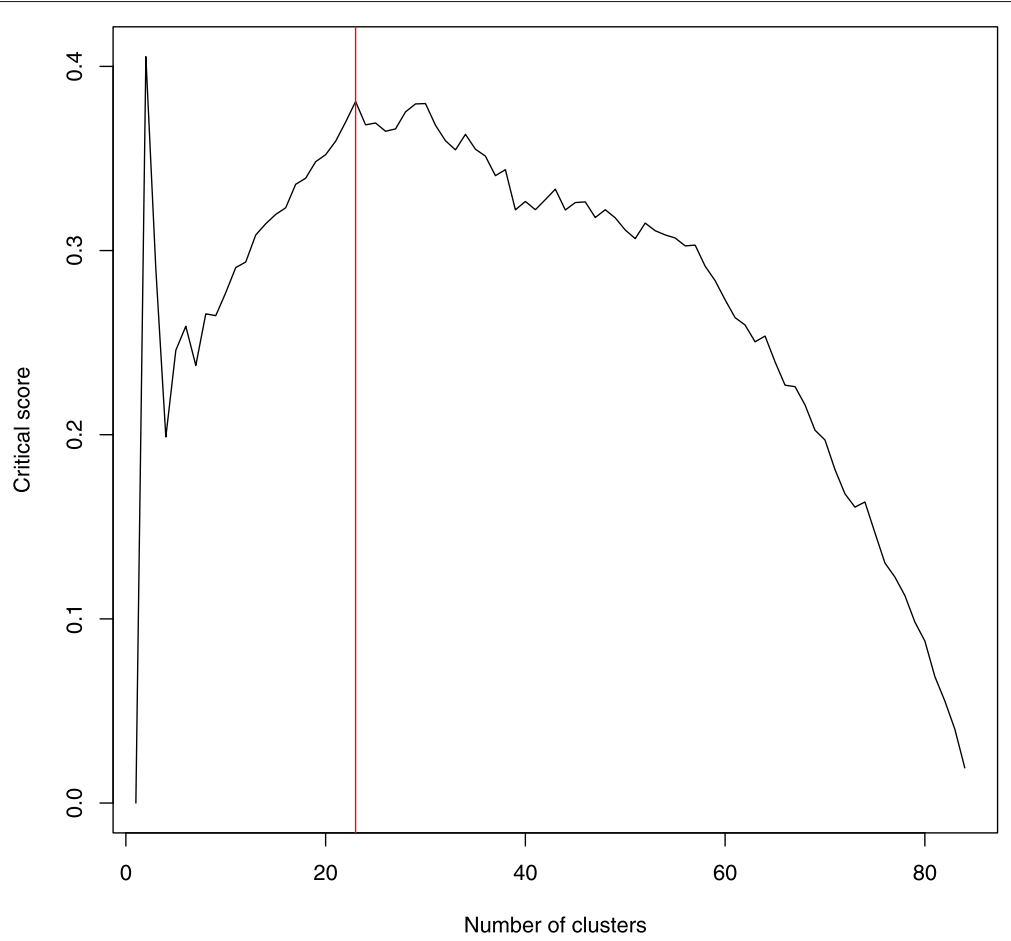

Fig. 1 Optimal number of clusters. Optimal number of clusters defined by partitioning around the medoids clustering (PAMK) based on geographical coordinates and climatic variables

from 0.24 to 0.40 while the genotype-level broad-sense heritability ranged from 0.09 to 0.25 . The population-level broad-sense heritability for EPI ranged from 0.01 to 0.02 while the genotype-level heritability ranged from 0.09 to 0.18 (Table 1).

\section{Genotype x environment interaction}

Broad-sense genetic correlations between environments (Tables 2 and 3) were used to investigate the interaction between populations and environment $(\mathrm{PxE})$. Important population genetic components were found for $\mathrm{DBH}$, which resulted in high and statistically significant genetic correlations between environments at the population level ranging from 0.98 to 0.99 (Table 2). These results did not indicate any important PxE interaction across the investigated environments at the population level, but the moderate genetic correlations were determined at a genotype level for the same trait, ranging from 0.60 to 0.91 (Table 2). The highest genetic correlation was found between the Awaho and Taranaki sites, confirming the results found in a previous analysis [23]. No statistically significant genetic correlation between sites at the population level was found for EPI, which reflected the negligible population variance components (Table 3 - above diagonal). However, broad-sense genetic correlations between sites at the genotype level were high and were mostly statistically significant (Table 3 - below diagonal). An exception was between the Awaho and Ngapuke farms sites, where the correlation was 0.42 (Table 3). These results indicated mostly only subtle changes in genotype ranking in EPI among sites except for the Awaho and Ngapuke farms sites, which caused large shifts in ranks. Changes in genotype ranking were also investigated, and the performance of some individuals was found to be more stable than others (Figs. 3 and 4), indicating high genotype differences in sensitivity to different environments.

\section{Universal response function}

We investigated climate variables on the prediction of productivity through Universal response function (URF) [16]. Since the coast redwood occupies relatively uniform environment centered in a fog belt within the Californian coastal area, most of the climatic variables investigated in this study showed high pairwise positive or negative correlations (Table 4) which resulted in URF model singularity. Therefore only two climatic variables with a moderate correlation of -0.55 (Tmax and precipitation) were considered in the final URF model. The proportion of variance explained by the model in term of $R^{2}$ reached 0.972 . The statistically most significant variables were Tmax and precipitation at the planted sites in New Zealand as well as their squared terms. The square term of Tmax was only significant climatic variable at origin (Table 5). The highest contribution to the variance explained by the URF 

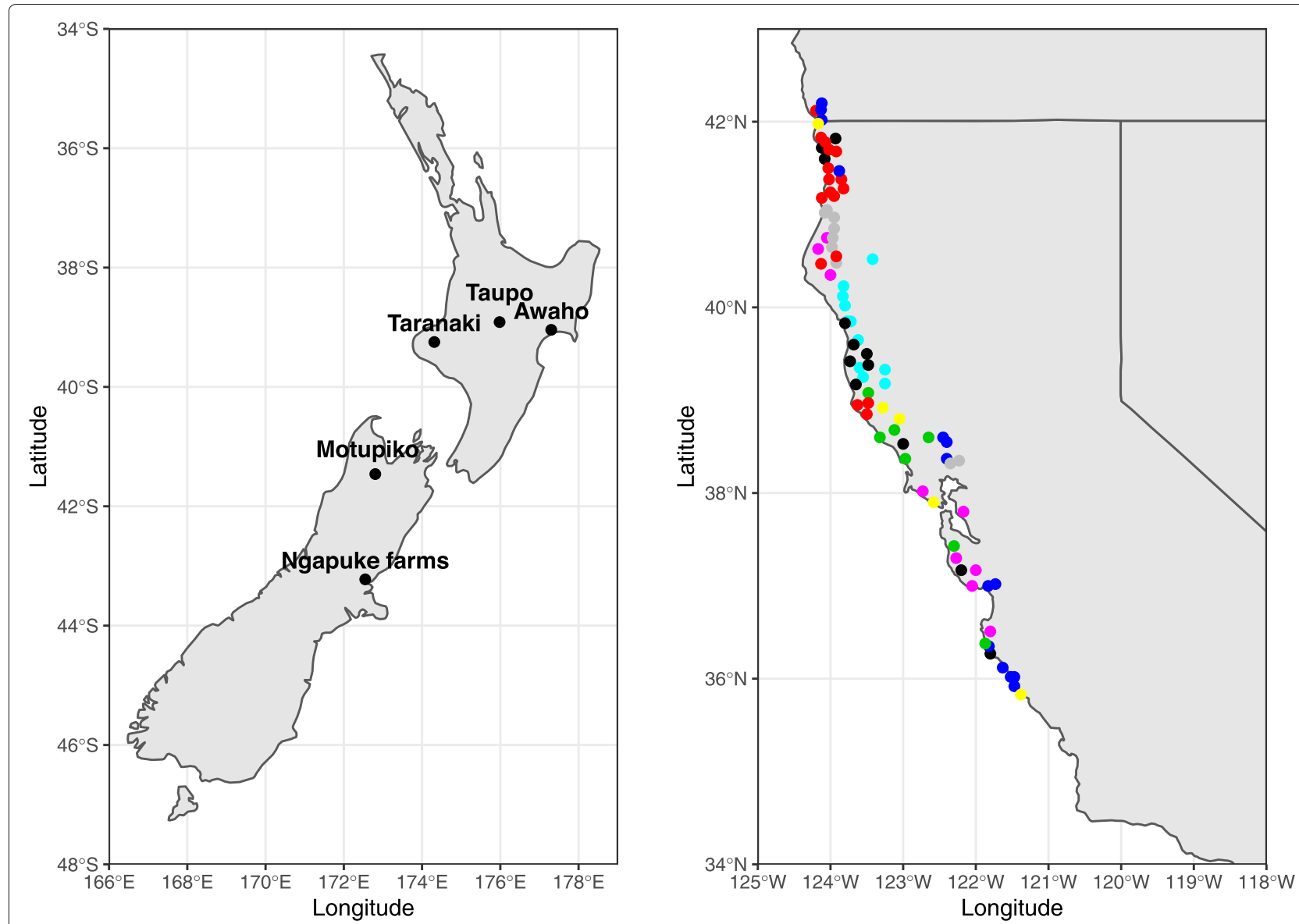

Fig. 2 Map of sample distribution. Geographical distribution of sites across New Zealand (left) and distribution of population in coast redwood sample (colours represent population clusters defined by PAMK algorithm) (right) (Figure created in this study using R packages "ggplot2" [24] and "maps" [25])

Table 1 Variance components and broad-sense heritability estimates

\begin{tabular}{|c|c|c|c|c|c|}
\hline Trait & Param. & Awaho & Taranaki & Moupiko & Ngapuke f. \\
\hline & Pop & $0.41(0.15-0.98)$ & $0.35(0.06-1.00)$ & $0.24(0.08-0.66)$ & $0.46(0.21-1.17)$ \\
\hline & Gen & $0.35(0.26-0.49)$ & $0.28(0.20-0.38)$ & $0.23(0.15-0.33)$ & $0.15(0.08-0.23)$ \\
\hline & Rep & $0.00(0.00-0.01)$ & $0.00(0.00-0.01)$ & $0.01(0.00-0.06)$ & $0.02(0.00-0.11)$ \\
\hline \multirow[t]{7}{*}{ DBH } & Rep(Block) & $0.00(0.00-0.01)$ & $0.00(0.00-0.01)$ & $0.00(0.00-0.02)$ & $0.00(0.00-0.02)$ \\
\hline & Error & $0.65(0.60-0.72)$ & $0.68(0.62-0.73)$ & $0.74(0.68-0.81)$ & $0.64(0.51-0.85)$ \\
\hline & $H^{2}$ - Pop. & $0.29(0.14-0.50)$ & $0.30(0.10-0.53)$ & $0.24(0.09-0.41)$ & $0.40(0.22-0.58)$ \\
\hline & $H^{2}$ - Gen. & $0.25(0.16-0.33)$ & $0.19(0.12-0.29)$ & $0.18(0.11-0.26)$ & $0.09(0.05-0.16)$ \\
\hline & Pop & $0.02(0.00-0.07)$ & $0.02(0.00-0.09)$ & $0.02(0.00-0.07)$ & $0.01(0.00-0.12)$ \\
\hline & Gen & $0.11(0.06-0.17)$ & $0.08(0.05-0.14)$ & $0.15(0.10-0.24)$ & $0.06(0.11-0.27)$ \\
\hline & Rep & $0.00(0.00-0.04)$ & $0.02(0.00-0.10)$ & $0.02(0.00-0.10)$ & $0.00(0.00-0.03)$ \\
\hline \multirow[t]{4}{*}{ EPI } & Rep(Block) & $0.01(0.00-0.04)$ & $0.01(0.00-0.04)$ & $0.01(0.00-0.04)$ & $0.01(0.00-0.03)$ \\
\hline & Error & $0.87(0.79-0.95)$ & $0.87(0.80-0.95)$ & $0.81(0.74-0.90)$ & $0.83(0.75-0.90)$ \\
\hline & $H^{2}$ - Pop. & $0.02(0.00-0.07)$ & $0.02(0.00-0.08)$ & $0.01(0.00-0.07)$ & $0.02(0.00-0.10)$ \\
\hline & $H^{2}-$ Gen. & $0.11(0.06-0.16)$ & $0.09(0.05-0.14)$ & $0.16(0.10-0.23)$ & $0.18(0.11-0.25)$ \\
\hline
\end{tabular}

Variance components, broad-sense heritabilities and their $95 \%$ confidence limits for each site and trait obtained from multi-environment model 
Table 2 Genetic correlations for DBH

\begin{tabular}{|c|c|c|c|c|}
\hline $\mathrm{DBH}$ & Awaho & Taranaki & Motupiko & Ngapuke farms \\
\hline Awaho & 1 & $0.99(0.89-0.99)$ & $0.99(0.91-0.99)$ & $0.99(0.93-0.99)$ \\
\hline Taranaki & $0.91(0.80-0.98)$ & 1 & $0.99(0.84-0.99)$ & $0.99(0.89-0.99)$ \\
\hline Motupiko & $0.64(0.43-0.80)$ & $0.66(0.44-0.81)$ & 1 & $0.98(0.90-0.99)$ \\
\hline Ngapuke farms & $0.75(0.49-0.92)$ & $0.74(0.49-0.92)$ & $0.60(0.31-0.85)$ & 1 \\
\hline
\end{tabular}

Between sites broad-sense genetic correlations at population (above diagonal) and genotype (below diagonal) level and their $95 \%$ confidence limits for DBH

model showed Tmax and precipitation at planted sites (Table 5). The URF model was implemented as a tool to predict the performance of the best cluster identified on the basis of quantitative genetic analysis across New Zealand using Tmax and precipitation information (Fig. 5) extracted from WorldClim database [26]. We found reasonable predictability within an area of planted sites (North Island and the north part of South Island) while poor performance was observed outside tested areas in the south of South Island (Fig. 6).

\section{Discussion}

\section{Genetic background}

Extensive natural distributions of forest trees over highly variable environments predispose the adaptive traits of forest trees to exhibit the effects of strong local natural selection. This effect can result in different phenotypic responses from different populations when compared using common garden experiments [28-30]. This is likely to be the case for DBH in coast redwood, which shows a considerable difference in phenotypic expression among populations when tested outside its natural distribution [23] and confirmed across more sites in this study. Interestingly, the differences in total DBH (a measure of productivity) between populations were larger compared to the within-population component (Table 1). This result indicates that natural selection has a strong effect. In contrast, previous studies of indigenous stands of this species in North America using molecular markers found high genetic variation within populations while only subtle variation between populations [31] and only weak and statistically non-significant level of genetic differentiation due to population structure in terms of Wright's fixation index $\mathrm{F}_{\mathrm{ST}}(0.0031)$ [32]. These findings correspond to the general notion that growth aligns with forest tree adaptive traits, as growing fast maximises the competitive ability of individual trees for a light interception in a forest [33]. Significant differences in productivity among populations have also been found in other forest tree species, such as poplars [9, 10] and European beech [30] by comparing genetic differentiation of quantitative traits between populations $\left(\mathrm{Q}_{\mathrm{ST}}\right)$ and genetic differentiation between populations based on selectively neutral markers $\left(\mathrm{F}_{\mathrm{ST}}\right)$ $[34,35]$. In this study, diameter at breast height (DBH) was the only attribute representing tree growth. Studies across other forest tree species found strong/moderate correlations between DBH and tree height or volume [36-39] which provides evidence of using $\mathrm{DBH}$ as an ideal proxy phenotype for other essential attributes. However, there is decent genetic variability found in $\mathrm{DBH}$ - tree height relationship due to differences in individual's response to environment and competition [40].

Genetic variance and interaction of the genetic and environmental components were investigated at both the population and genotype level. The population-level broad-sense genetic correlations between sites for $\mathrm{DBH}$ exceeded 0.7 , so the PxE interaction was considered to be non-significant [41]. Since the investigation of genotype by environment $(\mathrm{GxE})$ requires the presence of both genetic and environmental variance, the Taupō site was removed from the analysis due to lack of genetic component. We hypothesize that it was due to the low productivity at the site, which we discuss further below. Similar to our study, the missing genetic component was found for drought tolerance in Norway spruce when tested outside the range of species natural distribution [42]. Some GxE interactions at the genotype-within-population level were found when broad-sense genetic correlations between

Table 3 Genetic correlations for EPI

\begin{tabular}{llll}
\hline EPI & Awaho & Taranaki & Motupiko \\
\hline Awaho & 1 & $0.70(-0.45-0.95)$ & $0.60(-0.55-0.92)$ \\
Taranaki & $0.83(0.54-0.95)$ & 1 & $0.31(-0.76-0.86)$ \\
Motupiko & $0.78(0.50-0.94)$ & $0.85(0.55-0.97)$ & 1 \\
Ngapuke farms & $0.42(0.09-0.74)$ & $0.73(0.44-0.92)$ & $0.80(-0.50-0.97)$ \\
\hline
\end{tabular}

Between sites broad-sense genetic correlations at population (above diagonal) and genotype (below diagonal) level and their $95 \%$ confidence limits for EPI 


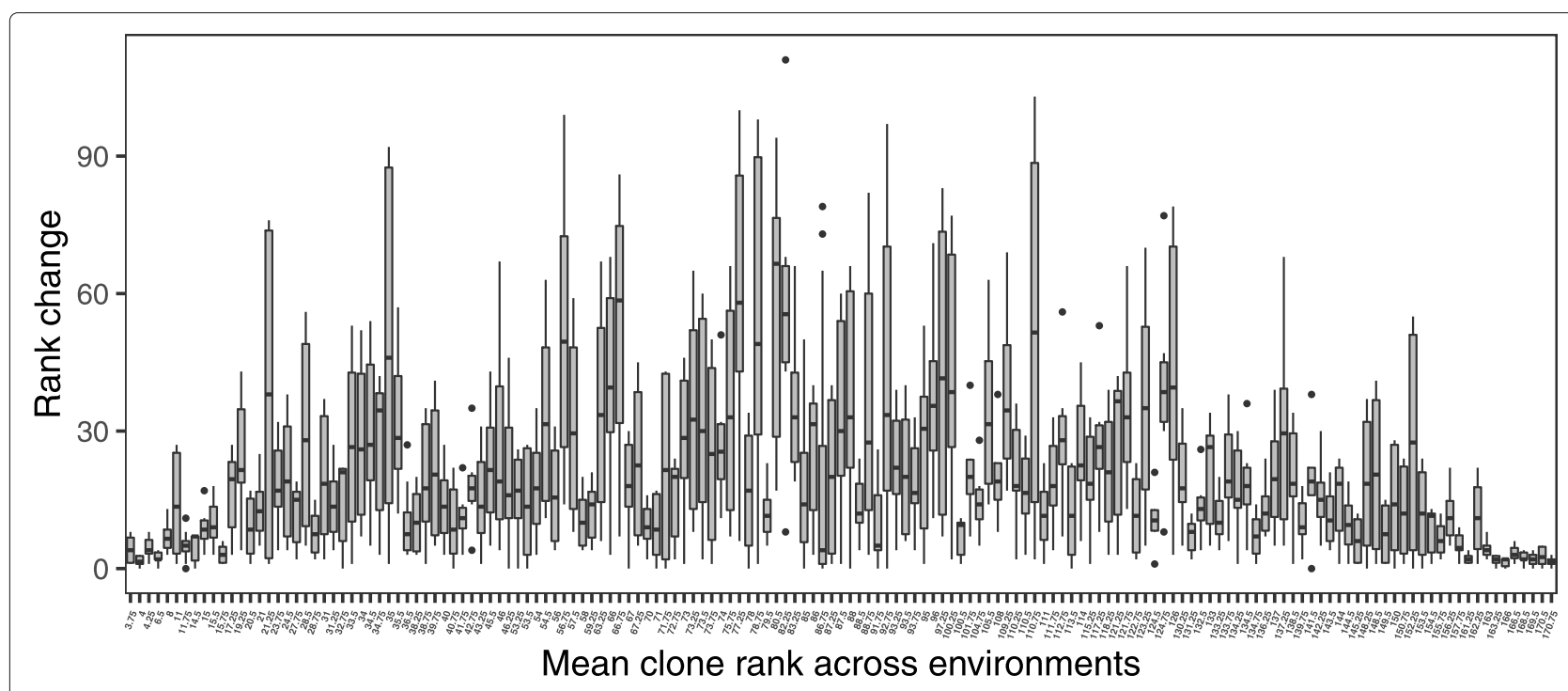

Fig. 3 Genotype by environment interaction in DBH. Rank change of the genotype performance for DBH across four environments

sites decreased slightly below 0.7 in most cases, except Awaho - Taranaki and Awaho - Ngapuke farms. The existence of a GxE interaction at the genotype level when suboptimal sites were involved in the evaluation is possibly due to the sensitivity of coast redwood growth to inbreeding depression. Inbred individuals may perform well under optimal conditions, but their productivity will decrease relative to outbred individuals under stressed conditions [43-45]. Moreover, thanks to intensive vegetative propagation through epicormic sprouts, coast redwood in natural forest stands have been known for the creation of polycormons up to at least 40 meters [31, 46], highlighting the likelihood of the occurrence of inbreeding. The results of this study suggest that young genotypes with unknown pedigrees should, therefore, be tested in moderately stressed environments to eliminate them for use in pedigreed progeny tests [44].

Some individuals were found to have large changes in ranking across environments compared with others (Figs. 3 and 4). We postulate that these individuals may originate from inbreeding. The molecular marker-based analysis could be used to determine whether or not this is the case. Coast redwood is a spontaneous polyploid, presumably developed through genome duplication

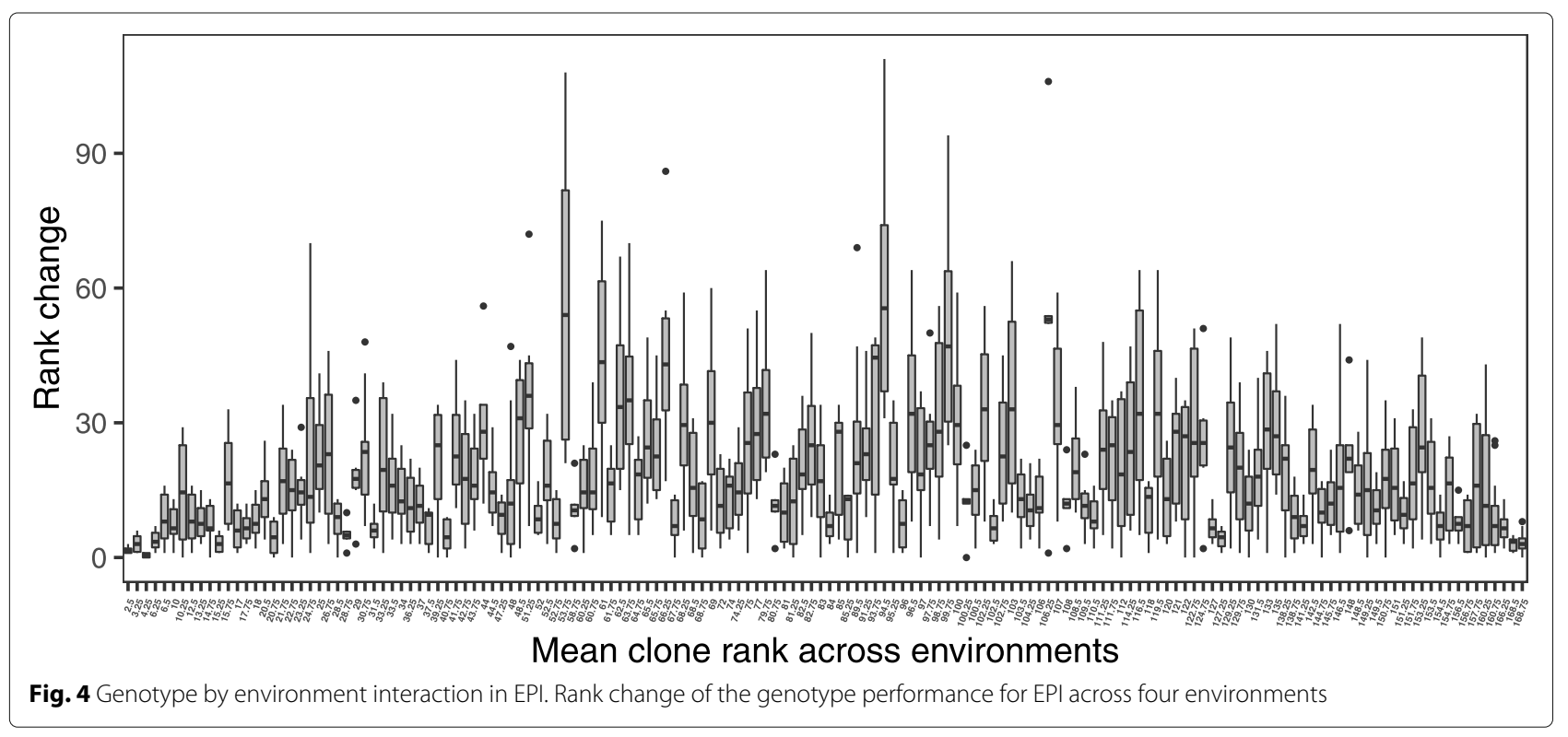


Table 4 Correlations between climatic and geographical variables

\begin{tabular}{lllllllll}
\hline & Long. & Lat. & Tmax. & Tmin. & Precip. & Radiation & WVP & Wind speed \\
\hline Long. & 1 & 0.84 & 0.59 & 0.57 & 0.09 & 0.83 & 0.52 & -0.16 \\
Lat. & 0.95 & 1 & 0.51 & 0.68 & 0.48 & 0.98 & 0.75 & 0.02 \\
Tmax. & -0.93 & -0.93 & 1 & 0.92 & -0.30 & 0.60 & 0.82 & 0.02 \\
Tmin. & -0.89 & -0.95 & 0.88 & 1 & 0.07 & 0.78 & 0.97 & 0.24 \\
Precip. & 0.66 & 0.51 & -0.55 & -0.62 & 1 & 0.48 & 0.24 & 0.54 \\
Radiation & -0.96 & -0.94 & 0.91 & 0.96 & -0.75 & 1 & 0.83 & 0.12 \\
WVP & -0.92 & -0.98 & 0.94 & 0.98 & -0.55 & 0.95 & 0.96 & 1 \\
Wind speed & -0.87 & -0.90 & 0.82 & 0.97 & -0.76 & 0.96 & 0.93 & 1 \\
\hline
\end{tabular}

Correlation between climatic variables (Tmax - mean daily maximum temperature, Tmin - mean daily minimum temperature, Precip - annual precipitation, WVP - water vapour pressure) and geographical coordinates (Lat - latitude, Long - longitude) at locations of origin (below diagonals) and at planted sites (above diagonals)

[47], which can introduce obstacles to the generation of genomic resources. However, several studies have successfully developed and implemented genetic markers in this species $[32,48]$. Current development of high-throughput genotyping technologies [49] can generate a significant number of markers to construct marker-based relationship matrices, even in wild populations [50] and thus allow for the investigation of individual inbreeding coefficients [51]. Besides, this genomic information can be used to infer genetically relevant population structures, which could substitute the cluster analysis and provide a more realistic estimate of population genetic variance, as well as an inference about the adaptive potential of studied traits through comparison of genetic differentiation detected in quantitative traits and neutral genetic markers (QST versus $\mathrm{F}_{\mathrm{ST}}$ ).

The appearance of epicormic sprouts on trees was found to be strongly influenced by genotype, but this was less obvious when fitting the population component. This pattern was the opposite of that observed for $\mathrm{DBH}$ and could imply that the EPI trait is not under natural selection. The production of epicormic sprouts presents a means of regenerating the understorey after wildfires [52] which are unlikely to be confined in such a way that causes strong local natural selection. This reasoning is supported by the fact that the ability to produce epicormic sprouts was observed across the whole sample set. The broad-sense heritability for EPI ranged from 0.08 to 0.19 , which was low but consistent with previous studies $[23,53]$. The low heritability indicates that environmental factors influence the phenotypic expression more than genetics, or that the main part of genetic variance has been already fixed. An experimental study that focused on the effect of pruning O'Hara and Berrill [54] found that the genetic component diminished a few years after the initiation of epicormic sprouts.

Table 5 Universal response function

\begin{tabular}{|c|c|c|c|c|}
\hline Variable & Estimate & t-val & P-val & $R^{2}$ \\
\hline Intercept & $114(0.996)$ & 114.98 & $<0.0001$ & \\
\hline Tmax_US & $16.59(12.47)$ & 1.331 & 0.186197 & 0.09 \\
\hline Tmax_US² & $39.57(11.23)$ & 3.524 & 0.000634 & 0.11 \\
\hline Tmax_NZ & $-483.94(27.23)$ & -17.769 & $<0.0001$ & 0.95 \\
\hline Tmax_NZ2 & $1146.77(25.31)$ & 45.312 & $<0.0001$ & 0.95 \\
\hline Tmax_US*Tmax_NZ & $36.22(114.81)$ & 0.315 & 0.7531 & 0.00 \\
\hline Prec_US & $22.46(12.74)$ & 1.763 & 0.0808 & 0.01 \\
\hline Prec_US² & $9.77(10.93)$ & 0.894 & 0.3734 & 0.01 \\
\hline Prec_NZ & $-974.91(27.68)$ & -35.218 & $<0.0001$ & 0.88 \\
\hline Prec_NZ2 & $-869.41(24.82)$ & -35.03 & $<0.0001$ & 0.92 \\
\hline Prec_US*Prec_NZ & $26.72(116.40)$ & 0.230 & 0.8189 & 0.00 \\
\hline$R^{2}$ & & 0.972 & & \\
\hline
\end{tabular}

The results from universal response function using climatic variables: mean daily maximum temperature at origin (Tmax_US), mean daily maximum temperature at planted site (Tmax_NZ), total annual precipitation at origin (Prec_US) and total annual precipitation at planted site (Prec_NZ) 

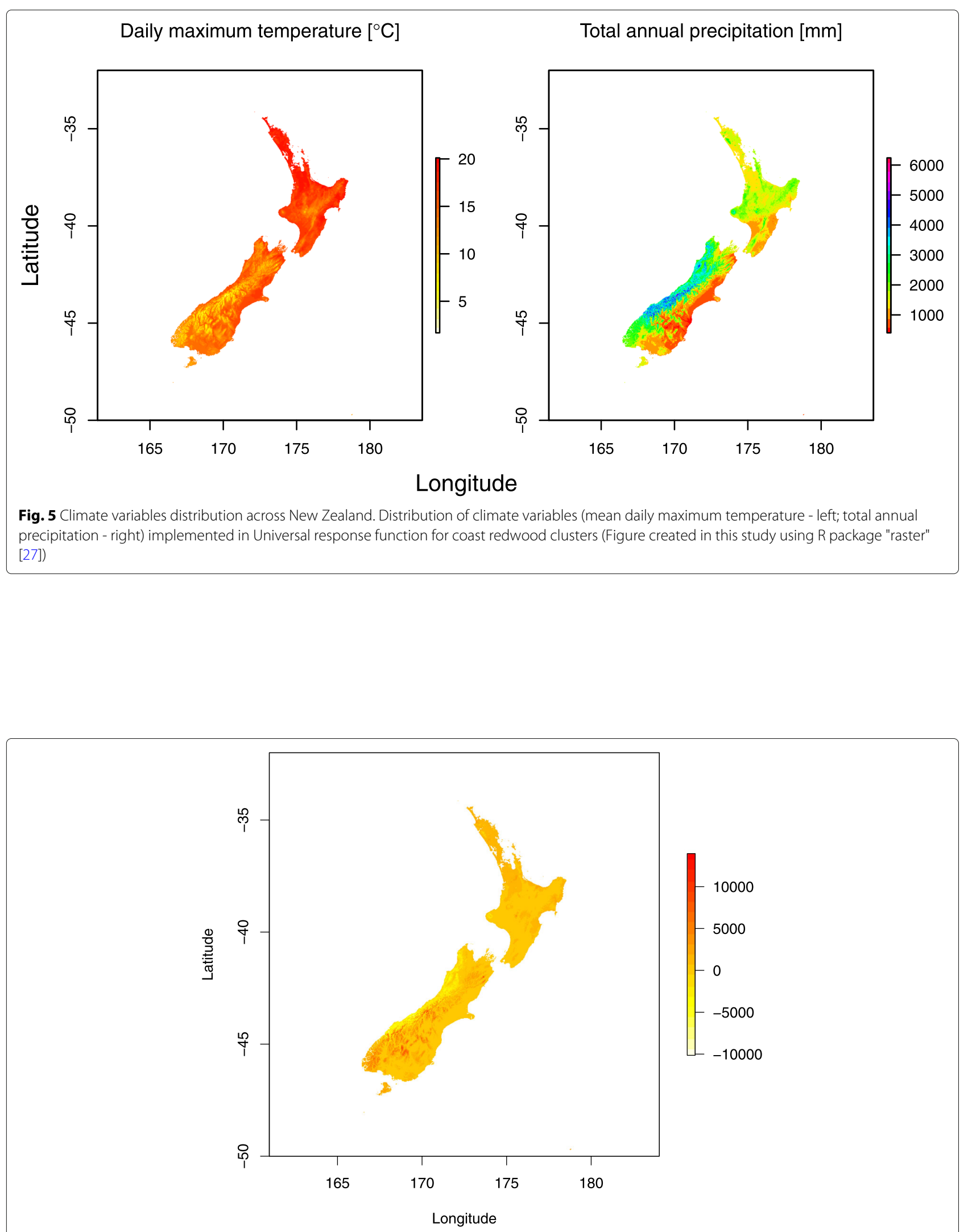

Fig. 6 Predicted performance of the genetically best material (Cluster 19) across New Zealand. Predicted DBH [mm] using maximum temperature and precipitation implemented in Universal Response Function (Figure created in this study using R package "raster [27]) 
This investigation of the PxE interaction found high but non-significant broad-sense genetic correlations across environments at the population level, which is assumed to be connected to a negligible variance component estimate for the effect of populations. The GxE interaction generally showed stable expression in terms of broad-sense genetic correlations between environments at a genotype level. A strong GxE interaction was found only between the Awaho and Ngapuke farms sites (Table 3). The differences in genotype ranking across these two sites can be related to a different level of phenotypic expression. While the Ngapuke farms site showed the highest broad-sense heritability for EPI, the Awaho site showed the lowest (Table 1). However, the persistence of an estimable genetic component should be re-evaluated when the trees are older [54].

\section{Environmental cues}

The analysis of individual sites showed significant genetic components at four of the five sites examined. Virtually no genetic component was found in either of the studied traits at the Taupō site (Additional file 1: Table S1). Trees at the Taupō site received $\sim 100-350 \mathrm{~mm}$ more annual precipitation than the other sites (Table 6) but had sandy pumice soil that would drain rapidly, and the volcanic soils in the region typically have low nutrients [55]. The low water retention of sandy soils can create elevated stress through lack of water accessibility during summer drought. Water accessibility is a significant factor affecting coast redwood growth [23], and fog is an important source of moisture for naturally occurring US coast redwood forest stands $[20,56]$. Additionally, the fog has been identified as a significant direct and indirect source of nitrogen to coast redwood trees [57]. The presence of drought stress causes a decrease in stem water potential and increases in the occurrence of stem embolisms, which is more pronounced in coast redwood compared with giant redwood [21]. Interestingly, their study also failed in finding any population differences in growth under stressed conditions; however, they investigated longitudinal rather than coast - inland pattern. We hypothesize that the lack of an estimable genetic component at Taupō could be caused by the fast-drying, free-draining soil which can cause water limitations for coast redwood, perhaps contributed to by the relatively poor rooting system of the species compared with others in the Sequoia genus [21]. Larger sized estimates of genetic components/heritability can generally be reached under optimal growing conditions, where the expression of underlying genetics is also optimal or close to optimal. Any sub-optimal conditions such as environmental stress can result in the reduction and potential disappearance of the expression of the underlying genetic potential and the reduction in the estimated genetic component $[42,58]$. Hence, it is likely that the conditions at the Taupō site are limiting for the growth of planted coast redwood in New Zealand.

Our study attempted to identify the climate variables that affect coast redwood productivity in New Zealand through the implementation of the universal response function. However, the potential of universal response function (URF) to achieve this goal was rather limited due to the fact that coast redwood occupies ecologically relatively uniform environment and most of the investigated climate variables were highly correlated (Table 4 - above diagonals). Consequently, the UFR model resulted in the singularity issue when more than two variables were included. Therefore, exploration of colinearity between variables is required to avoid any singularity in the URF model when species occupies environmentally/geographically narrow space. Our final model contained only two variables that show only moderate correlation (mean daily maximum temperature and total annual precipitation). The limited number of variables included in the URF model can restrict the informativeness of the model to predict species productivity reliably. It is worth to mention at this point that we used climatic

Table 6 Description of planted sites

\begin{tabular}{|c|c|c|c|c|c|}
\hline Climate var. & Awaho & Taranaki & Taupō & Motupiko & Ngapuke farms \\
\hline Soil type & Silt loam & Fine sandy loam & Sand & Silt loam & Hill soil \\
\hline Rooting $[\mathrm{m}]$ & 1.2 & 1.35 & 0.34 & 0.82 & 0.57 \\
\hline Soil order & Recent & Allophanic & Pumice & Brown & Pallic \\
\hline $\operatorname{Tmax} \cdot\left[\mathrm{C}^{\circ}\right]$ & 16.6 & 16.5 & 15.4 & 15.3 & 13.9 \\
\hline $\operatorname{Tmin}\left[\mathrm{C}^{\circ}\right]$ & 7.2 & 7.8 & 5.5 & 5.9 & 4.9 \\
\hline Rain. [mm] & 1506 & 1740 & 929 & 1564 & 2007 \\
\hline Solar rad. & 173483 & 173278 & 165250 & 172300 & 168396 \\
\hline Water vapour press. & 1.05 & 1.16 & 0.91 & 0.99 & 0.90 \\
\hline Wind speed & 4.5 & 4.6 & 4.1 & 3.8 & 4.7 \\
\hline
\end{tabular}

Environmental conditions at investigated sites: soil type, estimated rooting depth, soil order, mean annual rainfall (Rain.), mean daily maximum temperature (Tmax) and mean daily minimum temperature (Tmin) 
data available in WorldClim database [26]. There are other potentially useful resources of climate variables such as FAO agroclimatic databases and mapping tools [59] or NASA's distributed active archive centres (DAAC) [60].

The implemented URF model indicated the climate variables (mean daily maximum temperature and total annual precipitation) at planted sites as the most significant factors affecting productivity in New Zealand along with the quadratic term of mean daily maximum temperature at the origin. In contrary, an only a weak signal was detected in climate variables at origin (Table 5). The non-significance of climate variables at origin can be related to a relatively small number of tested genotypes per each level of climate variable despite a broader range of magnitudes compared to climate variables at planted sites. Additionally, the environmental variables represent coarse level environmental variables and do not reflect potentially important intra-annual climatic dynamics (e.g. number of dry days between precipitation events, precipitation event duration and intensity), which could be important factors for growth and stress for individual provenances. Research with other tree species has found some genotypes are more sensitive to microsite and climate than others [61]. The dendrochronological study conducted in situ on standing Californian coast redwood trees found a latitudinal pattern in climate sensitivity with a strong contrast between cooler northern rainforests and warm and dry southern forests. A negative relationship between radial growth and cloudiness of the local environment was found in trees growing in northern or central latitudes whereas a negative relationship was found between growth and dry summers in trees located at southern latitudes. Cloudiness is thought to reduce the amount of sunlight in reaching the surface of the needles, which reduces photosynthesis and leads to less radial growth [62].

Additionally, total annual precipitation is coarse environmental parameter as it does not reflect the variability in precipitation distribution and intensity throughout the year, which may be more critical for plant adaptation to cope with summer drought. In coast redwood's natural range, fog water is a significant water source, especially for coastal populations [45]. It has been estimated that fog contributes 25 to $50 \%$ of total annual water input for coast redwood ecosystems, and decreases with increasing distance from the ocean [20,63]. Conversely, New Zealand rarely gets summer fog, let alone the frequency of coastal California. Thus, it is unlikely to be a significant water site for the five sites at any time of the year. Unlike California, the majority of areas in New Zealand regularly receive precipitation throughout the year due to its maritime climate - although less precipitation during summer. It is unknown if New Zealand's maritime climate and regular precipitation act as an effective substitute for fog water during the summer, and if New Zealand grown redwood is more water-stressed during this period. Anekonda et al. [64] found a strong correlation between canonical variables inferred from growth increment, and respiratory variables, implying respiration may be correlated with growth. Estimates of the efficiency of each individual tree's energy metabolism showed that highly productive genotypes are less energy-efficient compared with less productive genotypes, something that appears to be contradictory.

The universal response function [16, 65] has already been implemented to predict population performance outside the range of species' natural distribution in the case of Douglas-fir in Central Europe [66] or white spruce in Canada [67]. The URF developed in this study explained $88 \%$ of the variation in data which is very similar to our results. Additionally, the authors found that conditions at planted sites are more significant compared to conditions at population origin, which is similarly found in our study. Chakraborty et al. [66] found the advantage of the empirical models such as URF over the climate envelope models and recommended their implementation, especially in case of productivity predictions outside of species' natural distribution.

The URF model was implemented to predict the productivity of genetically superior material identified in quantitative genetic analysis (Cluster 19) across New Zealand. The results show the best performance at the north of North Island (Northland) as well as the coastal line along the east coast of North Island. These regions were identified in the previous study using data from permanent sample plots analyse by multiple regression model [68]. However, the predictions outside the range of the tested environments produced unreliable estimates, especially in the southwest of South Island. This can be attributed partially to the lack of tested environments as well as to the limited number of environmental variables included in the URF model. We expect that the inclusion of more tested environments would allow for better estimation of co-linearity between environmental variables at tested sites and thus their better selection for the final model. Therefore, more detailed exploration of genotype $x$ environment interaction through universal response function would require a larger sample size tested across more environments.

\section{Conclusion}

The current study provides evidence of the ability to detect a heritable component of phenotypic variation in productivity, as measured with $\mathrm{DBH}$, and epicormic sprouts in a sample of coast redwood outside its natural conditions. However, also environmental conditions under which genetic component was suppressed were detected. The investigation of genotype $\mathrm{x}$ environment 
interaction did not discover any serious interaction of population/genotype with the environment. However, some combinations of sites showed slight effects in genotype ranking, specifically for particular genotypes which were attributed to possible selfing. Nevertheless, such hypothesis will need to be approved by the implementation of genetic markers. The implementation of universal response function allowed for the identification of important environmental factors affecting species productivity. Additionally, this approach enabled us to predict the performance of species across the New Zealand environmental conditions. In combination with quantitative genetic analysis which identified genetically superior material, the URF model can directly identify the optimal geographical regions to maximize productivity. However, the finding of ideally uncorrelated climatic variables for species with narrow ecological amplitude is rather challenging, which complicates construction of informative URF model. This, along with a small number of tested environments, tended to overfit a prediction model which resulted in extreme predictions in untested environments.

\section{Methods}

\section{Plant material}

Coast redwood material was collected in 1984 from 98 locations along the west coast of USA representing most of its natural distribution, i.e. from Curry County (OR) to Monterey County (CA) (Fig. 1) [23]. Seedlings were collected where possible, with saplings or stump sprouts obtained if no seedlings were available. A total of 198 genotypes representing all 98 different geographical locations were clonally propagated. Of these, a set of 182 genotypes representing 85 locations ( $1-6$ genotypes/location (Additional file 1: Table S2)) was imported into New Zealand in 2000, clonally propagated and used to establish a series of clonal trials across New Zealand between 2003 and 2006. A more detailed description of the material can be found in [23]. All individuals were phenotyped for diameter at breast height (DBH) and epicormic sprouts (EPI). Ageing from the different types of material is likely to have differed, but the data on the origin of the cuttings was not available, so this will be confounded with the results.

\section{Trial sites}

Eleven field trials were established, and data from five of these trials having the most complete sample data representation are analysed here. Three sites were in the North Island and two in the South Island of New Zealand (Fig. 2). Details of the sites are given in Table 6. The sites represented a range of environmental conditions. The Awaho and Taranaki sites were situated on fertile soils with abundant precipitation, which corresponded to coast redwood's optimum growth conditions. The Ngapuke farm site had a much lower annual precipitation and was planted on a northwest slope that dries out in summer. The Taupo site received more precipitation than two of the other sites but had sandy soil. Previous analyses [23] have been undertaken on only two sites. Each genotype at each site was represented by several identical copies (ramets) planted in incomplete block design.

\section{Climatic variables}

Climatic variables such as mean daily minimum temperature $\left[\mathrm{C}^{\circ}\right]$ and mean daily maximum temperature $\left[\mathrm{C}^{\circ}\right]$, annual precipitation $[\mathrm{mm}]$, solar radiation $\left[\mathrm{kJ} \mathrm{m}^{-2}\right.$ day $\left.^{-1}\right]$, water vapour pressure $[\mathrm{kPa}]$ and wind speed $[\mathrm{m} / \mathrm{s}]$ were extracted from WolrdClim database version 2 (http:// worldclim.org/version2) [26] as monthly averages across 1970-2000 period. The variables related to temperature, solar radiation and wind speed were averaged across months while precipitation was summed across months for downstream analysis.

\section{Statistical evaluation}

Each location was represented by 1 - 6 trees (Additional file 1: Table S2), so population structure was inferred by using partitioning around the medoids clustering algorithm implemented using the "pamk" function available in the "fpc" $R$ package [69]. The geographical coordinates (latitude, distance from the coast and elevation) and climatic variables (annual precipitation, annual daily temperature maximum and minimum) (Additional file 1: Table S2) were used as inputs to create groups of genotypes from geographically discrete and environmentally homogeneous regions. Genetic parameters, such as genetic variance (including both additive and non-additive components), broad-sense heritability and genetic correlations between different environments were estimated through a multivariate generalised mixed model based on Monte Carlo Markov Chain sampling [70] as follows:

$$
Y=X \beta+Z p+Z g+Z r+Z r(b)+e
$$

where $\boldsymbol{Y}$ is a matrix of phenotypes, $\boldsymbol{\beta}$ is the vector of fixed effects (intercept), $\boldsymbol{p}$ is the vector of random population effects following $\operatorname{var}(\boldsymbol{p}) \sim \mathrm{N}(0, \mathrm{G} 1)$, where $\mathrm{G} 1$ is variancecovariance structure of population effects following $\mathrm{G1}=$ $\left[\begin{array}{ccc}\sigma_{p_{1}}^{2} & \ldots & \sigma_{p_{1} p_{n}} \\ \vdots & \ddots & \vdots \\ \sigma_{p_{n} p_{1}} & \cdots & \sigma_{p_{n}}^{2}\end{array}\right] \otimes \boldsymbol{I}$, where $\sigma_{p_{1}}^{2}$ and $\sigma_{p_{n}}^{2}$ are population variances for the $1^{\text {st }}$ and $\mathrm{n}^{\text {th }}$ environment, $\sigma_{p_{n} p_{1}}$ and $\sigma_{p_{1} p_{n}}$ are population covariances between the $1^{\text {st }}$ and $n^{\text {th }}$ environment, $\otimes$ is the Kronecker product and $I$ is the identity matrix. The vector $\boldsymbol{g}$ is vector of random genotype within population effects following $\operatorname{var}(\boldsymbol{g}) \sim \mathrm{N}(0, \mathrm{G} 2)$, where $\mathrm{G} 2$ is 
variance-covariance structure of genotype within population effects following $G 2=\left[\begin{array}{ccc}\sigma_{g_{1}}^{2} & \ldots & \sigma_{g_{1} g_{n}} \\ \vdots & \ddots & \vdots \\ \sigma_{g_{n} g_{1}} & \ldots & \sigma_{g_{n}}^{2}\end{array}\right] \otimes \boldsymbol{I}$, where $\sigma_{g_{1}}^{2}$ and $\sigma_{g_{n}}^{2}$ are genotype within population variances for the $1^{\text {st }}$ and $\mathrm{n}^{\text {th }}$ environment. The vector $r$ is vector of random replication effects following $\operatorname{var}(\boldsymbol{r}) \sim \mathrm{N}(0, \mathrm{G} 3)$, where G3 is variance-covariance structure of replication effect following $G 3=\left[\begin{array}{ccc}\sigma_{r_{1}}^{2} & \ldots & \sigma_{r_{1} r_{n}} \\ \vdots & \ddots & \vdots \\ \sigma_{r_{n} r_{1}} & \ldots & \sigma_{r_{n}}^{2}\end{array}\right] \otimes I$, where $\sigma_{r_{1}}^{2}$ and $\sigma_{r_{n}}^{2}$ are replication variances for the 1 st and nth environment. The vector $\boldsymbol{r}(\boldsymbol{b})$ is vector of random block nested within replication effects following $\operatorname{var}(\boldsymbol{r}(\boldsymbol{b})) \sim \mathrm{N}(0, \mathrm{G} 4)$, where G4 is the variance-covariance structure for block nested within replication effects following G4 $=\left[\begin{array}{ccc}\sigma_{r(b)_{1}}^{2} & \ldots & \sigma_{r(b)_{1} r(b)_{n}} \\ \vdots & \ddots & \vdots \\ \sigma_{r(b)_{n} r(b)_{1}} & \cdots & \sigma_{r(b)_{n}}^{2}\end{array}\right] \otimes I$, where $\sigma_{r(b)_{1}}^{2}$ and $\sigma_{r(b)_{n}}^{2}$ are block nested within replication variances for the $1^{\text {st }}$ and $\mathrm{n}^{\text {th }}$ environment. The vector $\boldsymbol{e}$ is vector of random residuals (effect of ramet within genotype) following $\operatorname{var}(\boldsymbol{e}) \sim \mathrm{N}(0, \mathrm{R})$, where $\mathrm{R}$ is residual variance-covariance structure following $\mathrm{R}=\left[\begin{array}{ccc}\sigma_{e_{1}}^{2} & \ldots & \sigma_{e_{1} e_{n}} \\ \vdots & \ddots & \vdots \\ \sigma_{e_{n} e_{1}} & \cdots & \sigma_{e_{n}}^{2}\end{array}\right] \otimes I$, where $\sigma_{e_{1}}^{2}$ and $\sigma_{e_{n}}^{2}$ are residual variances for the $1^{\text {st }}$ and $n^{\text {th }}$ environments, $X$ and $Z$ are the incidence matrices assigning fixed and random effects to measurements in matrix $\boldsymbol{Y}$. Broad-sense heritability at population level was estimated as follows:

$$
H_{p}^{2}=\frac{\sigma_{p}^{2}}{\sigma_{p}^{2}+\sigma_{g}^{2}+\sigma_{e}^{2}}
$$

where $\sigma_{p}^{2}$ is posterior mode of population variance, $\sigma_{g}^{2}$ is posterior mode of genotype variance and $\sigma_{e}^{2}$ is posterior mode of residual variance. Similarly, the broad-sense heritability at genotype level was estimated as follows:

$$
H_{g}^{2}=\frac{\sigma_{g}^{2}}{\sigma_{p}^{2}+\sigma_{g}^{2}+\sigma_{e}^{2}}
$$

The broad-sense genetic correlation between sites at the population level to define population $\mathrm{x}$ environments interaction was estimated using Pearson product-moment estimate as follows:

$$
r_{G E_{p}}=\frac{\sigma_{p_{i} p_{j}}}{\sqrt{\sigma_{p_{i}}^{2} \sigma_{p_{j}}^{2}}}
$$

where $\sigma_{p_{i} p_{j}}$ is posterior mode of population covariance between $\mathrm{i}^{\text {th }}$ and $\mathrm{j}^{\text {th }}$ environment, $\sigma_{p_{i}}^{2}$ and $\sigma_{p_{j}}^{2}$ are posterior modes of population variance at environments $i$ and $\mathrm{j}$, respectively. Similarly, the broad-sense genetic correlation between sites at genotype level to define genotype $x$ environment interaction was estimates as follows:

$$
r_{G E_{g}}=\frac{\sigma_{g_{i} g_{j}}}{\sqrt{\sigma_{g_{i}}^{2} \sigma_{g_{j}}^{2}}}
$$

where $\sigma_{g_{i} g_{j}}$ is posterior mode of genotype covariance between $\mathrm{i}^{\text {th }}$ and $\mathrm{j}^{\text {th }}$ environment, $\sigma_{g_{i}}^{2}$ and $\sigma_{g_{j}}^{2}$ are posterior modes of genotype variance at environments $i$ and $j$, respectively. All analyses were performed in R 'base' package [71] with implementation of 'MCMCglmm' package [70]. The phenotypic data were standardised to have mean 0 and variance 1 [72]. The number of iterations was set to 500,000 and burn-in period was 50,000 runs. Thinning was set to 10 .

The graphical investigation of $\mathrm{GxE}$ at the individual level was investigated through the construction of boxplots. The individuals were ranked in each environment regarding their performance, and average clonal ranking was estimated as arithmetical mean of genotype ranks across investigated environments. Box of each genotype then represents the dispersion of pair-wise change in rankings between environments. In this way, we can investigate behaving of individuals generally ranked as the best, poor or average.

The universal response function was constructed by using climatic variables at origin as well as at planted sites following [16]:

$$
Y_{i j}=b_{0}+b_{1} X_{1 i}+b_{2} X_{1 i}^{2}+b_{3} X_{2 j}+b_{4} X_{2 j}^{2}+b_{5} X_{1 i} X_{2 j}+e_{i j}
$$

\section{Supplementary information}

Supplementary information accompanies this paper at https://doi.org/10.1186/s12863-020-0821-1.

Additional file 1: Supplemental tables. The Additional file 1 contains Table S1 summarizing variance components and broad-sense heritability from single site analysis and Table $\$ 2$ describing climatic and geographical variables related to each sampling site in US.

Additional file 2: Phenotypic data. The Additional file 2 contains all phenotypic data used in this study.

\section{Abbreviations}

CA: California; DBH: Diameter at breast height; EPI: Epicormic sprouts; GxE: Genotype by environment interaction; Lat: Latitude; Long: Longitude; OR: Oregon; Prec_NZ: Total annual precipitation at planted site; Prec_US: Total annual precipitation at origin; PXE: Phenotype by environment interaction; Tmax_NZ: Mean daily maximum temperature at planted site; Tmax_US: Mean daily maximum temperature at origin; Tmin: Mean daily minimum temperature; URF: Universal response function; US: The United States of America; WV: Water vapour pressure

Acknowledgements

We would like to thank to Charlie Low for data pre-processing and archiving. 


\section{Authors' contributions}

JK performed analyses and drafted manuscript, DM, HD and ET made substantial contributions to conception, PS and SR data acquisition. All authors have approved the submitted version of the manuscript and have agreed both to be personally accountable for the author's own contributions and to ensure that questions related to the accuracy or integrity of any part of the work, even ones in which the author was not personally involved, are appropriately investigated, resolved, and the resolution documented in the literature.

\section{Funding}

The study was financially supported by Ministry of Primary Industry through Special Farm Forestry project \#404886. The funding body played no role in the design of the study and collection, analysis, and interpretation of data and in writing the manuscript.

\section{Availability of data and materials}

All phenotypic data and used in the study is available in Additional file 2.

\section{Ethics approval and consent to participate}

Not applicable.

\section{Consent for publication}

Not applicable.

\section{Competing interests}

The authors declare that they have no competing interests.

\section{Author details}

${ }^{1}$ Scion (New Zealand Forest Research Institute Ltd.), 49 Sala Street, 3010 Rotorua, New Zealand. ${ }^{2}$ NZ Forestry Ltd., 701 A Pollen Street, 3500 Thames, New Zealand. ${ }^{3}$ The New Zealand Redwood Company, P.O. Box 1343, 3351 Taupō, New Zealand.

Received: 26 September 2019 Accepted: 31 January 2020 Published online: 10 February 2020

\section{References}

1. Melillo JM, McGuire AD, Kicklighter DW, Moore B, Vorosmarty CJ, Schloss AL. Global climate change and terrestrial net primary production. Nature. 1993;363(6426):234-40.

2. Bonan GB. Forests and climate change: forcings, feedbacks, and the climate benefits of forests. Science. 2008;320(5882):1444-9.

3. Pan Y, Birdsey RA, Fang J, Houghton R, Kauppi PE, Kurz WA, et al. A large and persistent carbon sink in the world's forests. Science. 2011;333(6045):988-93.

4. Bellard C, Bertelsmeier C, Leadley P, Thuiller W, Courchamp F. Impacts of climate change on the future of biodiversity. Ecol Lett. 2012;15(4):365-77.

5. Matyas C. Climatic adaptation of trees: rediscovering provenance tests. Euphytica. 1996;92(1-2):45-54

6. Kremer A, Potts BM, Delzon S. Genetic divergence in forest trees: understanding the consequences of climate change. Funct Ecol. 2014;28(1):22-36

7. Mimura M, Aitken S. Adaptive gradients and isolation-by-distance with postglacial migration in Picea sitchensis. Heredity. 2007;99(2):224-32.

8. McKown AD, Guy RD, Klápště J, Geraldes A, Friedmann M, Cronk QC, et al. Geographical and environmental gradients shape phenotypic trait variation and genetic structure in Populus trichocarpa. New Phytol. 2014;201(4):1263-76.

9. Porth I, Klápště J, McKown AD, La Mantia J, Guy RD, Ingvarsson PK, et al. Evolutionary quantitative genomics of Populus trichocarpa. PLOS ONE. 2015:10(11):0142864.

10. Evans LM, Kaluthota S, Pearce DW, Allan GJ, Floate K, Rood SB, et al. Bud phenology and growth are subject to divergent selection across a latitudinal gradient in Populus angustifolia and impact adaptation across the distributional range and associated arthropods. Ecol Evol. 2016;6(13): 4565-81.

11. Vitasse $Y$, Delzon S, Bresson CC, Michalet R, Kremer A. Altitudinal differentiation in growth and phenology among populations of temperate-zone tree species growing in a common garden. Can J Forest Res. 2009:39(7):1259-69.
12. Aitken SN, Yeaman S, Holliday JA, Wang T, Curtis-McLane S. Adaptation, migration or extirpation: climate change outcomes for tree populations. Evol Appl. 2008;1(1):95-111.

13. Gray LK, Hamann A. Strategies for reforestation under uncertain future climates: guidelines for Alberta, Canada. PLoS ONE. 2011;6(8):22977.

14. Gray LK, Gylander T, Mbogga MS, Chen P-y, Hamann A. Assisted migration to address climate change: recommendations for aspen reforestation in western Canada. Ecol Appl. 2011;21(5):1591-603.

15. Aitken SN, Bemmels JB. Time to get moving: assisted gene flow of forest trees. Evol Appl. 2016;9(1):271-90.

16. Wang T, O'Neill GA, Aitken SN. Integrating environmental and genetic effects to predict responses of tree populations to climate. Ecol Appl. 2010;20(1):153-63.

17. Jones DA, O'hara KL. Carbon density in managed coast redwood stands: implications for forest carbon estimation. Forestry. 2011;85(1):99-110.

18. Potter $C$. Net primary production and carbon cycling in coast redwood forests of central California. Open J Ecol. 2012;2(03):147-53.

19. Noss RF. The Redwood Forest: History, Ecology, and Conservation of the Coast Redwoods. Washington DC: Island Press; 1999.

20. Dawson TE. Fog in the California redwood forest: ecosystem inputs and use by plants. Oecologia. 1998;117(4):476-85.

21. Ambrose AR, Baxter WL, Wong CS, Næsborg RR, Williams CB, Dawson TE. Contrasting drought-response strategies in California redwoods. Tree Physiol. 2015;35(5):453-69.

22. Roy DF, Vol. 28. Silvical characteristics of redwood (Sequoia sempervirens [D. Don] Endl.). Res. Paper PSW-RP-28. Berkeley: Pacific Southwest Forest \& Range Experiment Station Forest Service, US Department of Agriculture; 20 p; 1966.

23. Meason D, Kennedy S, Dungey H. Two New Zealand-based common garden experiments of the range-wide 'Kuser'clonal collection of Sequoia sempervirens reveal patterns of provenance variation in growth and wood properties. New Forest. 2016;47(4):635-51.

24. Wickham H. ggplot2. Wiley Interdiscip Rev Comput Stat. 2011;3(2):180-5.

25. Murrell P. R Graphics. Boca Raton FL: CRC Press; 2018

26. Fick SE, Hijmans RJ. WorldClim 2: new 1-km spatial resolution climate surfaces for global land areas. Int J Climatol. 2017;37(12):4302-15.

27. Hijmans RJ, Van Etten J, Cheng J, Mattiuzzi M, Sumner M, Greenberg JA Lamigueiro OP, Bevan A, Racine EB, Shortridge A, Hijmans MRJ. Raster: Geographic data analysis and Modeling. 2018. R package version 3-07. Available at: http://CRAN.R-project.org/package=raster, (accessed on 3 Nov 2019).

28. Kremer A, Le Corre V, Mariette S. Population differentiation for adaptive traits and their underlying loci in forest trees: theoretical predictions and experimental results. In: Forest Genetics and Sustainability. Heidelberg: Springer; 2000. p. 59-74.

29. O'Brien EK, Mazanec RA, Krauss SL. Provenance variation of ecologically important traits of forest trees: implications for restoration. J Appl Ecol. 2007:44(3):583-93.

30. Gömöry D, Ditmarová L, Hrivnák M, Jamnická G, Kmet' J, Krajmerová D, et al. Differentiation in phenological and physiological traits in European beech (Fagus sylvatica L). Eur J For Res. 2015;134(6):1075-85.

31. Rogers DL. Genotypic diversity and clone size in old-growth populations of coast redwood (Sequoia sempervirens). Can J Bot. 2000;78(11):1408-19.

32. Douhovnikoff $\mathrm{V}$, Dodd RS. Lineage divergence in coast redwood (Sequoia sempervirens), detected by a new set of nuclear microsatellite loci. Am Midl Nat. 2011;165(1):22-37.

33. King DA. The adaptive significance of tree height. Am Nat. 1990;135(6): 809-28.

34. Whitlock MC, Guillaume F. Testing for spatially divergent selection: comparing OST to FST. Genetics. 2009:183(3):1055-63.

35. Merilä J, Crnokrak P. Comparison of genetic differentiation at marker loci and quantitative traits. J Evolution Biol. 2001;14(6):892-903.

36. Svensson J, McKeand S, Allen H, Campbell R. Genetic variation in height and volume of loblolly pine open-pollinated families during canopy closure. Silvae Genet. 1999;48:204-8.

37. Yang H, Liu T, Liu C, Wang J, Chen K, Zhong W, Chen B, Huang S. Genetic parameters and efficiency of early selection for half rotation-aged growth and form traits in Pinus taeda in china. Silvae Genet. 2013;62(1-6): $277-84$ 
38. de Lima BM, Cappa EP, Silva-Junior OB, Garcia C, Mansfield SD, Grattapaglia D. Quantitative genetic parameters for growth and wood properties in Eucalyptus "urograndis" hybrid using near-infrared phenotyping and genome-wide snp-based relationships. PLoS ONE. 2019;14(6):0218747.

39. Lenz PR, Nadeau S, Mottet M-J, Perron M, Isabel N, Beaulieu J, Bousquet J. Multi-trait genomic selection for weevil resistance, growth, and wood quality in Norway spruce. Evol Appl. 2020;13(1):76-94.

40. Kroon J, Andersson B, Mullin TJ. Genetic variation in the diameter-height relationship in Scots pine (Pinus sylvestris). Can J For Res. 2008;38(6): 1493-503.

41. Johnson G. Site-to-site genetic correlations and their implications on breeding zone size and optimum number of progeny test sites for coastal Douglas-fir. Silvae Genet. 1997:46:280-5.

42. Klisz M, Buras A, Sass-Klaassen U, Puchalka R, Koprowski M, Ukalska J. Limitations at the limit? Diminishing of genetic effects in Norway spruce provenance trials. Front Plant Sci. 2019;10:306.

43. Libby W, McCutchan B, Millar C, et al. Inbreeding depression in selfs of redwood. Silvae Genet. 1981;30(1):15-25.

44. Rydelius J, Libby W. Arguments for redwood clonal forestry. In: Clonal Forestry II. Heidelberg: Springer; 1993. p. 158-68.

45. Sawyer JO, Sillett SC, Libby WJ, Dawson TE, Popenoe JH, Largent DL, Van Pelt R, Veirs Jr SD, Noss RE, Thornburgh DA, et al. Redwood trees, communities, and ecosystems: a closer look. In: Noss RF, editor. The Redwood Forest: History, Ecology, and Conservation of the Coast Redwoods. Washington DC: Island Press; 2000. p. 81-118.

46. Douhovnikoff V, Cheng AM, Dodd RS. Incidence, size and spatial structure of clones in second-growth stands of coast redwood, Sequoia sempervirens (Cupressaceae). Am J Bot. 2004;91(7):1140-6.

47. Scott AD, Stenz NW, Ingvarsson PK, Baum DA. Whole genome duplication in coast redwood (Sequoia sempervirens) and its implications for explaining the rarity of polyploidy in conifers. New Phytol. 2016;211(1): 186-93.

48. Toral Ibanez M, Caru M, Herrera MA, Gonzalez L, Martin LM, Miranda J, et al. Clones identification of Sequoia sempervirens (D, Don) Endl. in Chile by using PCR-RAPDs technique. J Zhejiang Univ SC B. 2009;10(2):112-9.

49. Elshire RJ, Glaubitz JC, Sun Q, Poland JA, Kawamoto K, Buckler ES, et al. A robust, simple genotyping-by-sequencing (GBS) approach for high diversity species. PLoS ONE. 2011;6(5):19379.

50. El-Kassaby YA, Klápště J, Guy RD. Breeding without breeding: selection using the genomic best linear unbiased predictor method (GBLUP). New Forest. 2012;43(5-6):631-7.

51. Wang J. Marker-based estimates of relatedness and inbreeding coefficients: an assessment of current methods. J Evol Biol. 2014;27(3): 518-30.

52. Ramage BS, O'Hara K, Caldwell B. The role of fire in the competitive dynamics of coast redwood forests. Ecosphere. 2010;1(6):1-18.

53. Anekonda T, Libby W. Effectiveness of nearest-neighbor data adjustment in a clonal test of redwood. Silvae Genet. 1996;45(1):46-51.

54. O'Hara KL, Berrill J-P. Epicormic sprout development in pruned coast redwood: pruning severity, genotype, and sprouting characteristics. Ann For Sci. 2009;66(4):409.

55. MacLaren RG, Cameron KC. Soil science: an introduction to the properties and management of New Zealand soils. Oxford: Oxford University Press; 1990

56. Simonin KA, Santiago LS, Dawson TE. Fog interception by Sequoia sempervirens (D, Don) crowns decouples physiology from soil water deficit. Plant Cell Environ. 2009;32(7):882-92.

57. Templer PH, Weathers KC, Ewing HA, Dawson TE, Mambelli S, Lindsey AM, et al. Fog as a source of nitrogen for redwood trees: evidence from fluxes and stable isotopes. J Ecol. 2015;103(6):1397-407.

58. Hoffmann AA, Merilä J. Heritable variation and evolution under favourable and unfavourable conditions. Trends Ecol Evol. 1999;14(3):96-101.

59. Gommes R, Grieser J, Bernardi M. Fao agroclimatic databases and mapping tools. Eur Soc Agron Newsl. 2004;22:32-6.

60. Scott D, Brennan J, Harrison S, Jones C, Morris K, Schroeder C, Schumacher J, Wilson J, Wolf $\mathrm{V}$. The nasa daacs support earth science users' data needs. In: AGU Fall Meeting Abstracts. San Francisco; 2006.

61. Gallart M, Love J, Meason DF, Coker G, Clinton PW, Xue J, Jameson PE, Klápště J, Turnbull MH. Field-scale variability in site conditions explain phenotypic plasticity in response to nitrogen source in Pinus radiata D, Don. Plant Soil. 2019;443:353-68.

62. Carroll AL, Sillett SC, Kramer RD. Millennium-scale crossdating and inter-annual climate sensitivities of standing California redwoods. PLoS ONE. 2014;9(7):102545.

63. Dawson TE. The use of fog precipitation by plants in coastal redwood forests. In: LeBlanc J, editor. Proceedings of the conference on coastal redwood forest ecology and management. Arcata: Humboldt State University; 1996. p. 90-3.

64. Anekonda T, Criddle R, Libby W, Breidenbach R, Hansen L. Respiration rates predict differences in growth of coast redwood. Plant Cell Environ. 1994;17(2):197-203.

65. Wang T, O'Neill GA, Aitken SN. Integrating environmental and genetic effects to predict responses of tree populations to climate. Ecol Appl. 2010;20(1):153-63.

66. Chakraborty D, Wang T, Andre K, Konnert M, Lexer MJ, Matulla C, Schueler S. Selecting populations for non-analogous climate conditions using universal response functions: The case of Douglas-fir in central Europe. PLoS ONE. 2015;10(8):0136357.

67. Yang J, Pedlar JH, McKenney DW, Weersink A. The development of universal response functions to facilitate climate-smart regeneration of black spruce and white pine in Ontario, Canada. For Ecol Manag. 2015;339:34-43.

68. Palmer DJ, Watt MS, Kimberley MO, Dungey HS. Predicting the spatial distribution of Sequoia sempervirens productivity in New Zealand. New Zeal J For Sci. 2012;42:81-9.

69. Hennig C, Liao TF. How to find an appropriate clustering for mixed-type variables with application to socio-economic stratification. J Roy Stat Soc C-Appl. 2013;62(3):309-69.

70. Hadfield JD. MCMC methods for multi-response generalized linear mixed models: the MCMCgImm R package. J Stat Softw. 2010;33(2):1-22.

71. R Core Team. R: A language and environment for statistical computing. R Foundation for Statistical Computing, Vienna, Austria. 2019. Version 3.5.3. https://www.R-project.org/, (accessed on 10 May 2019).

72. Holand AM, S teinsland I, Martino S, Jensen H. Animal models and integrated nested Laplace approximations. G3: Genes Genom Genet. 2013;3(8):1241-51.

\section{Publisher's Note}

Springer Nature remains neutral with regard to jurisdictional claims in published maps and institutional affiliations.
Ready to submit your research? Choose BMC and benefit from:

- fast, convenient online submission

- thorough peer review by experienced researchers in your field

- rapid publication on acceptance

- support for research data, including large and complex data types

- gold Open Access which fosters wider collaboration and increased citations

- maximum visibility for your research: over $100 \mathrm{M}$ website views per year

At $\mathrm{BMC}$, research is always in progress.

Learn more biomedcentral.com/submissions 